\title{
CHITOSAN-BASED HYDROGELS SUPPLEMENTED WITH GELATINE AND LINK N ENHANCE EXTRACELLULAR MATRIX DEPOSITION BY ENCAPSULATED CELLS IN A DEGENERATIVE INTERVERTEBRAL DISC ENVIRONMENT
}

\author{
A. Adoungotchodo ${ }^{1,2,3}$, L.M. Epure ${ }^{3}$, F. Mwale ${ }^{3,4}$ and S. Lerouge ${ }^{1,2, *}$ \\ ${ }^{1}$ Laboratory of Endovascular Biomaterials (LBeV), Centre de recherche du CHUM (CRCHUM), \\ Montreal, Canada \\ ${ }^{2}$ Department of Mechanical Engineering, École de Technologie Supérieure (ETS), Montreal, Canada \\ ${ }^{3}$ Lady Davis Institute for Medical Research, SMBD-Jewish General Hospital, Montreal, Canada \\ ${ }^{4}$ Division of Orthopaedic Surgery, McGill University, Montreal, Canada
}

\begin{abstract}
Injectable therapies for intervertebral disc (IVD) repair are gaining much interest. Recently, a chitosan (CH)based injectable scaffold has been developed that has similar mechanical properties to human nucleus pulposus (NP) and provides a suitable environment for encapsulated NP cell survival and proteoglycan production. The hypothesis of the study was that the biological response of the encapsulated cells can be further increased by adding gelatine and Link $\mathrm{N}$ (LN, a naturally occurring peptide present in cartilage and IVD extracellular matrix), known to increase cell adhesion and proteoglycan production, respectively. The effect of gelatine on the mechanical properties of a CH hydrogel was evaluated through rheological and compressive mechanical tests. Production of proteoglycan [assessed as glycosaminoglycan (GAG)] by encapsulated NP cells was determined in the presence or absence of gelatine in normal or degenerative medium supplemented with LN. Normal and degenerative media replicate the healthy and degenerative disc environment, respectively. Gelatine slightly reduced the gelation rate of $\mathrm{CH}$ hydrogel but improved its final mechanical properties in compression. LN had a minimal effect in normal medium but induced significantly more GAG production in degenerative medium ( $p<0.001,4.7$-fold superior to the control), reaching similar results to transforming growth factor (TGF)- $\beta$ (used as a positive control). GAG production was further increased in $\mathrm{CH}$-gelatine hydrogels, confirming an additive effect of LN and gelatine in a degenerative environment. The results supported the concept that $\mathrm{CH}$-gelatine hydrogels supplemented with LN can help restore the function of the NP during the early stages of IVD degeneration.
\end{abstract}

Keywords: Chitosan, intervertebral disc, Link N, gelatine, injectable hydrogel, nucleus pulposus.

*Address for correspondence: Sophie Lerouge, PhD, Laboratory for endovascular biomaterials (LBeV), CHUM research centre (CRCHUM), 900 St Denis St, Montreal, QC H2X 3H8, Canada.

Telephone number: +1 5143968836 Email: sophie.lerouge@etsmtl.ca

Copyright policy: This article is distributed in accordance with Creative Commons Attribution Licence (http://creativecommons.org/licenses/by-sa/4.0/).

\begin{tabular}{|c|c|c|c|}
\hline \multirow{4}{*}{ BGP } & List of Abbreviations & IL & interleukin \\
\hline & & IPN & interpenetrating polymer network \\
\hline & $\beta$-glycerophosphate disodium salt & IVD & intervertebral disc \\
\hline & hydrate & IVDD & intervertebral disc degeneration \\
\hline BMP & bone morphogenetic protein & LN & Link $N$ \\
\hline $\mathrm{CH}$ & chitosan & LVE & linear viscoelastic range \\
\hline DMEM & Dulbecco's modified Eagle's medium & NP & nucleus pulposus \\
\hline DMMB & dimethyl methylene blue & OP-1 & osteogenic protein 1 \\
\hline ECM & extracellular matrix & PBS & phosphate-buffered saline \\
\hline FAM & carboxyfluorescein & SD & standard deviation \\
\hline FBS & foetal bovine serum & SHC & sodium hydrogen carbonate \\
\hline GDF-5 & growth differentiation factor 5 & TGF- $\beta$ & transforming growth factor beta \\
\hline IGF & insulin-like growth factor & TNF- $\alpha$ & tumour necrosis factor alpha \\
\hline
\end{tabular}




\section{Introduction}

IVDD is a leading cause of chronic back pain and loss of function. It is a multifactorial disease, characterised by the loss of ECM, specifically proteoglycan and collagen, tissue dehydration, fissure development, loss of disc height, inflammation, endplate sclerosis, cell death and hyperinnervation of nociceptive nerve fibres (Freemont, 2009). There are no therapeutics for IVDD and the current first line treatment modalities are focused on pain management, but none target the underlying causes. Inadequately controlled pain is the main reason for invasive procedures such as discectomy, laminectomy, disc replacement and spinal fusion (Wu et al., 2020). Over 1.6 million instrumented surgical procedures are performed annually in the United States (Web ref. 1). Yet, despite the frequency of the most common procedure, spinal fusion, clinical success varies from 50 to $70 \%$. Pain relief is often short-lived and the altered biomechanics can lead to adjacent disc degeneration (Lee et al., 2015; Nguyen et al., 2011). Consequently, there is an unmet need for better and efficacious approaches that deal directly with the pathological state of the degenerated IVD.

One of the most important changes caused by IVDD is the loss of proteoglycans residing in the NP. These proteoglycans are hydrophilic glycoproteins responsible for attracting and retaining water molecules inside the disc (Shapiro and Risbud, 2013). Their high-water concentration confers important compressive capacity to the NP tissue, which is able to absorb and adequately distribute compressive loads to the spine (Gilchrist et al., 2011; O'Halloran and Pandit, 2007). Due to age and not well-known causes, NP proteoglycan content decreases gradually (Raj, 2008), leading to a reduction in the osmotic pressure of the discal matrix and an inadequate load redistribution leading to IVDD. Since it is difficult for the native NP to achieve self-renewal, any treatment which can enhance proteoglycan content in the NP may help to slow or stop the degeneration process and eventually regenerate the biomechanical properties of the disc (Iatridis et al., 2013).

Injectable cell therapy targeting the central gelatinous NP is a promising approach for biological repair. Various studies were intended to design injectable scaffolds containing cells and eventually a bioactive agent to optimise their function (Frith et al., 2013; Smith et al., 2014; Thorpe et al., 2016). An ideal injectable scaffold should provide a suitable environment for encapsulated cells to survive and produce ECM components while exhibiting similar mechanical properties to native tissue. Assaad et al. (2015) have recently developed a scaffold that fulfils these requirements. This scaffold is an injectable thermoresponsive $\mathrm{CH}$-based hydrogel that rapidly gels at body temperature. Thanks to the use of a combination of SHC and BGP, it presents similar mechanical properties to human NP and provides a suitable environment for the survival of encapsulated NP cells. However, previous results have shown a suboptimal synthesis of proteoglycans (Alinejad et al., 2019).

A strategy to increase proteoglycans synthesis by encapsulated cells is the addition of cell adhesive components in the hydrogel. Gelatine, obtained by denaturation of collagen (Gentile et al., 2016), is well known to increase cell proliferation (Xia et al., 2004) and adhesion through binding motifs recognised by cell integrin receptors (Huang et al., 2005; Zheng et al., 2018). Gilchrist et al. (2007) have shown that human disc cells attach to the collagen present in the ECM through alpha integrin receptors. The authors have also demonstrated the impact of mechanical properties and ECM ligands on NP cell activity. Indeed, they hypothesised that the presence of appropriate ECM ligands such as collagen and laminin in a suitable mechanical environment can lead to a higher proteoglycan production (Gilchrist et al., 2011). Based on those studies and the fact that gelatine is non-immunogenic (Jaipan et al., 2017), the study hypothesis was that adding gelatine in the $\mathrm{CH}$ hydrogel would improve cell attachment to the scaffold, increase cell survival and lead to enhanced proteoglycan synthesis.

In addition to cell adhesive components, growth factors such as TGF- $\beta$, GDF-5, BMP-2, IGF, OP-1 (or BMP-7) have been shown to increase the production of proteoglycans by discs cells (Alini et al., 2003; Bach et al., 2017; Kim et al., 2003; Smith et al., 2014). However, these bioactive agents may not be suitable for clinical applications, due to their risk of tumorgenicity (Brahmkhatri et al., 2015) and prohibitive cost. Therefore, LN peptide was proposed as an alternative.

LN is a naturally occurring 16 amino acid peptide representing the $\mathrm{N}$-terminal region of the Link protein, an endogenous glycoprotein that binds hyaluronic acid and aggrecan in both the IVD and articular cartilage and stabilises the resulting proteoglycan aggregates (Melching and Roughley, 1985). Previous studies have demonstrated that LN meets the criteria for an ideal IVDD treatment as it acts as an anabolic agent, reversing structural degradation of the IVD due to the disease, and blocks the inflammatory and pain-producing pathways (Antoniou et al., 2012; Bach et al., 2017; Gawri et al., 2012; Gawri et al., 2014; Mwale et al., 2011; Noorwali et al., 2018).

The objective of this study was to design an injectable therapy for IVD repair by associating the $\mathrm{CH}$ thermosensitive hydrogel with gelatine and $\mathrm{LN}$ as bioactive agents and investigate the effect of gelatine or/and LN addition on proteoglycan synthesis by encapsulated NP cells in CH hydrogels in vitro. First, rheological and compressive mechanical tests were conducted to assess the potential effect of gelatine on mechanical and gelation properties. Secondly, gelatine and/or LN effects on encapsulated NP cells 
survival and proteoglycan synthesis were evaluated in a condition replicating a healthy or degenerative disc environment.

\section{Materials and Methods}

\section{Source of $\mathrm{CH}$, gelatine and $\mathrm{LN}$}

$\mathrm{CH}$ powder (Kitomer, PSN 32850, molecular weight $250 \mathrm{kDa}, 95 \%$ deacetylated) was supplied by Marinard Biotech (Rivière-au-Renard, QC, Canada), while gelatine powder from porcine skin was obtained from Sigma-Aldrich (gelatine type A, G1890). LN (DHLSDNYTLDHDRAIH) was synthesised with a purity $>98 \%$ by CanPeptide (Pointe Claire, QC, Canada).

\section{Preparation of $\mathrm{CH}$ and $\mathrm{CH}$-gelatine hydrogels}

$\mathrm{CH}$ powder with or without gelatine was solubilised in $0.1 \mathrm{~mol} / \mathrm{L}$ of $\mathrm{HCl}$. Obtained $\mathrm{CH}$ or $\mathrm{CH}$-gelatine solutions were autoclaved $\left(121^{\circ} \mathrm{C}\right.$ for $\left.20 \mathrm{~min}\right)$ and stored at $4{ }^{\circ} \mathrm{C}$ until use. A gelling agent solution consisting of BGP (G9422, Sigma-Aldrich) and SHC (144-55-8, EMD Millipore Corporation) was prepared using deionised water and filtered through a $0.22 \mu \mathrm{m}$ membrane. Hydrogel solutions were prepared by mixing $\mathrm{CH}$ or $\mathrm{CH}$-gelatine solutions with the gelling agent solution at a volume ratio of $3: 2$ using two syringes and a Luer Lock (H93813904, Baxter, Zurich, Switzerland) syringe connector as previously described (Assaad et al., 2015). Tested formulations contained constant $\mathrm{CH} 2 \% \mathrm{w} / \mathrm{v}$ and gelling agent concentrations $(75 \mathrm{mmol} / \mathrm{L} \mathrm{SHC}+100 \mathrm{mmol} / \mathrm{L} \mathrm{BGP})$, with different concentrations of gelatine $(0,1,1.5$ and $2 \% \mathrm{w} / \mathrm{v})$.

\section{Hydrogel gelation kinetics}

Two different rheological tests were performed using a Physica MCR 301 rheometer (Anton Paar, Ostfildern, Germany) equipped with coaxial cylinder geometry (CC10/T200). First, the stability at room temperature and the thermoresponsivity of the hydrogels were evaluated. Just after preparation, $1.5 \mathrm{~mL}$ of hydrogel solution was poured into the rheometer. Storage $\left(G^{\prime}\right)$ and loss $\left(G^{\prime \prime}\right)$ moduli were monitored for $20 \mathrm{~min}$ at room temperature $\left(22^{\circ} \mathrm{C}\right)$, followed by $20 \mathrm{~min}$ at body temperature $\left(37^{\circ} \mathrm{C}\right)$. For the second test, the hydrogel solution was placed in the sample holder previously heated to $37^{\circ} \mathrm{C}$ and the gelation kinetic at body temperature was assessed by monitoring the evolution of the storage and loss moduli for $1 \mathrm{~h}$. Both oscillatory tests were performed in the LVE, at $1 \mathrm{~Hz}$ frequency and $1 \%$ strain (for stability test) or $5 \%$ strain (for gelation kinetic test).

\section{Unconfined compression}

$\mathrm{CH}$ and $\mathrm{CH}$-gelatine hydrogels solutions were prepared, poured into cylinders $(14 \mathrm{~mm}$ internal diameter) and left to gel at $37^{\circ} \mathrm{C}$ for $24 \mathrm{~h}$. The hydrogel discs obtained (approximatively $9 \mathrm{~mm}$ height) were used to measure unconfined compression properties. Compression tests were performed on each sample using a Mach-1 ${ }^{\mathrm{TM}}$ Micromechanical System (Biomomentum, Laval, Canada) equipped with a $250 \mathrm{~N}$ load cell. A deformation rate of $100 \%$ / min (approximatively $0.15 \mathrm{~mm} / \mathrm{s}$ ) was applied until $70 \%$ deformation to obtain stress-strain curves and to assess the secant modulus. The $15 \%$ secant modulus was calculated as the slope of a line connecting the point of zero strain to the $15 \%$ deformation point.

\section{Isolation of NP cells}

Bovine NP cells were isolated from fresh coccygeal IVDs obtained from 2-4 years old steers within $24 \mathrm{~h}$ of slaughter, as previously described (Alinejad et al., 2019; Gawri et al., 2012). Briefly, IVDs were dissected from the adjacent vertebral bodies and washed in PBS containing $100 \mu \mathrm{g} / \mathrm{mL}$ penicillin, $100 \mathrm{U} / \mathrm{mL}$ streptomycin, $50 \mu \mathrm{g} / \mathrm{mL}$ gentamicin and $0.25 \mu \mathrm{g} /$ $\mathrm{mL}$ Fungizone (Wisent Bioproducts, Montreal, QC, Canada). The NP regions were separated from the IVDs and cut into approximately $2 \mathrm{~mm}$ pieces. NP cells were enzymatically isolated from the tissue pieces by sequential digestion with $0.125 \%$ Pronase (Sigma-Aldrich) for $30 \mathrm{~min}$ followed by $16 \mathrm{~h}$ incubation with $50 \mathrm{U} / \mathrm{mL}$ collagenase I (C-9891, Sigma-Aldrich) at $37^{\circ} \mathrm{C}$. The obtained solution was filtered using a $75 \mu \mathrm{m}$ nylon cell strainer and the supernatant was centrifuged at 1,000 $\times g$ for $10 \mathrm{~min}$. The cellular pellet was washed twice with DMEM prior to seeding.

For all experiments, NP cells were expanded until passage 3 in DMEM (1 g/L glucose, 319-010CL, Wisent Inc., Saint-Jean-Baptiste, CQ, Canada) supplemented with $10 \%$ heat-inactivated FBS and $1 \%$ penicillin/streptomycin, with culture medium changed every $3 \mathrm{~d}$.

Encapsulation of cells in $\mathrm{CH}$ and $\mathrm{CH}$-gelatine gels Bovine NP cells were encapsulated in the hydrogels as follows: first, $0.6 \mathrm{~mL}$ of $\mathrm{CH}$ or $\mathrm{CH}$-gelatine solutions were mixed with $0.2 \mathrm{~mL}$ gelling agent solution with two syringes connected using a Luer Lock; then, the obtained mixture was mixed with $0.2 \mathrm{~mL}$ cell suspension $\left(10^{6}\right.$ cells $/ \mathrm{mL}$ as final cell density for cell viability or $10^{7}$ cells $/ \mathrm{mL}$ for GAG production assessment). Thus, final composition remained $2 \%$ $\mathrm{w} / \mathrm{v} \mathrm{CH}, 100 \mathrm{mmol} / \mathrm{L} \mathrm{BGP}$ and $75 \mathrm{mmol} / \mathrm{L} \mathrm{SHC}$ with $0,1,1.5$ or $2 \% \mathrm{w} / \mathrm{v}$ gelatine, as in mechanical characterisation tests. Then, this solution was placed in a 48 -wells plate $(200 \mu \mathrm{L} /$ well $)$ and incubated for $3 \mathrm{~min}$ at $37^{\circ} \mathrm{C}$. Culture medium $(500 \mu \mathrm{L} /$ well $)$ was further added in each well and the plate was maintained in the incubator at $37^{\circ} \mathrm{C}, 5 \% \mathrm{CO}_{2}$.

Two different culture media were tested: a normal medium (PrimeGrowth ${ }^{\mathrm{TM}}$ Disc Cells Medium, 319515-CL, Wisent Inc.) and a degenerative medium (PrimeGrowth ${ }^{\mathrm{TM}}$ Degenerative Disc Cells Medium, 319-513-CL, Wisent Inc.), supplemented with $1 \mathrm{ng} /$ mL IL-1 $\beta$ (SRP3083, Millipore). Each medium was supplemented with $10 \%$ FBS and $1 \%$ penicillin/ streptomycin. The normal medium was characterised 
by a physiological $\mathrm{pH}$ and high osmolarity and was developed to ensure optimal disc cells growth and functionality during in vitro culture. The degenerative medium was designed to simulate the biochemical composition of a degenerative disc (lower $\mathrm{pH}$ and osmolarity, higher mineral content, presence of inflammatory cytokine such as IL-1 $\beta$ ).

\section{LN diffusion in the gel}

Before testing the effect of LN on cells, LN diffusion in the $\mathrm{CH}$ and $\mathrm{CH}$-gelatine hydrogels when added to the medium was first confirmed. For that purpose, $50 \mu \mathrm{g}$ of fluorescent LN (LN labelled with 5-carboxyfluorescein, CP08245F, CanPeptide Inc., Pointe Claire, QC, Canada) in $500 \mu \mathrm{L}$ of complete culture medium was incubated with $200 \mu \mathrm{L}$ of hydrogel in 48 -wells plate. After 1,3 and $24 \mathrm{~h}$ incubation at $37^{\circ} \mathrm{C}$, LN concentration remaining in the medium was determined using a spectrophotometer in fluorescence mode (EX485/ EM520) and a calibration curve. Then, the amount of LN diffused in the gel was determined by subtracting the remaining LN in the medium from the initial LN quantity. Then, the LN concentration in the gel was compared to the concentration expected in the case of equilibrium $(71 \mu \mathrm{g} / \mathrm{mL})$, calculated by dividing the quantity of LN added in each well $(50 \mu \mathrm{g})$ by total volume in the well [hydrogel + medium $(700 \mathrm{~mL})]$.

Effect of gelatine and LN on encapsulated NP cells To study the effect of gelatine on NP-cell viability and GAG production, NP cells encapsulated either in $\mathrm{CH}$ or $\mathrm{CH}$-gelatine hydrogels were cultured in normal medium for $14 \mathrm{~d}$. To evaluate the effect of LN and select the optimal concentration, NP cells encapsulated in $\mathrm{CH}$ hydrogel were cultured in normal or degenerative medium supplemented with various concentrations $(0,10,25$ or $100 \mu \mathrm{g} / \mathrm{mL})$ of human LN for $14 \mathrm{~d}$. Then, the possible additive benefits of gelatine and LN were studied by encapsulating NP cells in $\mathrm{CH}$ or $\mathrm{CH}-1$ \% gelatine hydrogels and cultured in either normal or degenerative medium supplemented with 100 g/mL LN. 50 ng/mL TGF- $\beta$ (PHG9204, Invitrogen) was used as a positive control.

Cell viability was assessed by live/dead assay at day 1 and 14 on NP hydrogel scaffolds. Briefly, the hydrogel was washed with PBS and incubated for $45 \mathrm{~min}$ at $37{ }^{\circ} \mathrm{C}$ with serum-free medium supplemented with $2 \mu \mathrm{mol} / \mathrm{L}$ ethidium homodimer-3 and $1 \mu \mathrm{mol} / \mathrm{L}$ calcein-AM (LIVE/DEAD ${ }^{\mathrm{TM}}$ Cell Imaging Kit reagents, R37601, Life Technologies). The hydrogel was again washed with PBS and immediately observed using an inverted fluorescent microscope (Leica DM IRB). Cell viability was calculated as the ratio of live cells (green) to total cells number (green and red). The "Analyse particles function" in ImageJ (National Institute of Health) was used for the counting.

GAG production (released into the medium and retained in the construct) was analysed using the DMMB assay (Garnjanagoonchorn et al., 2007).
DNA content in the gel was measured at $14 \mathrm{~d}$ using the PicoGreen ${ }^{\circledR}$ assay (Quant-iT ${ }^{\mathrm{TM}}$ PicoGreen $^{\mathrm{TM}}$ dsDNA Assay Kit, Thermo Fisher Scientific) following manufacturer's protocol.

\section{Statistical analysis}

Results are presented as mean \pm SD. Statistical analysis was performed by using one-way ANOVA followed by Dunnett's multiple comparison test for studies comparing separately the effect of gelatine or LN concentrations on GAG production. Two-way ANOVA followed by Tukey's multiple comparison test was used to analyse simultaneously the effect of gelatine, LN, TGF- $\beta$ and medium type on GAG production. A $p<0.05$ was considered statistically significant. Each experiment was performed a minimum three times.

\section{Results}

\section{Effect of gelatine on rheological and unconfined compression properties of $\mathrm{CH}$ hydrogels}

The $\mathrm{CH}$ hydrogel used presents suitable mechanical properties for NP repair, i.e. quick gelation and compressive properties close to human NP tissue (Alinejad et al., 2019). However, GAG production by encapsulated NP cells was suboptimal compared to in vivo levels. In the present study, gelatine, a biodegradable and biocompatible protein, was added to the hydrogel, because of its cell adhesion properties, which may increase ECM deposition by NP cells. Gelatine was also chosen because of its nonantigenic characteristics when compared to collagen (Liang et al., 2004) and its physicochemical performances that can be modulated appropriately. However, adding gelatine to $\mathrm{CH}$ hydrogels can affect their mechanical properties, which are already suitable for the application. Therefore, the first step of the study consisted in evaluating the effect of various concentrations of gelatine $(1-2 \mathrm{w} / \mathrm{v} \%)$ on the scaffold gelation kinetics and compressive properties (Fig. 1).

All hydrogel formulations showed a relatively stable storage modulus $\left(G^{\prime}\right)$ at room temperature and sudden increase in $G^{\prime}$ when the temperature was increased up to $37^{\circ} \mathrm{C}$, confirming that they were all thermosensitive (Fig. 1a). However, gelatine had a dose-dependent impact on the rheological properties. Initial $\mathrm{G}^{\prime}$ (and viscosity, data not shown) at $22{ }^{\circ} \mathrm{C}$ increased slightly with gelatine concentration. Moreover, the increase in $\mathrm{G}^{\prime}$ with temperature was slower for $\mathrm{CH}$-gelatine hydrogels, suggesting that gelatine addition slowed down the gelation at $37^{\circ} \mathrm{C}$. However, the $1 \%$ gelatine formulation presented comparable gelation profile with the $\mathrm{CH}$ hydrogel.

These results were confirmed by the time sweep experiments performed directly at $37{ }^{\circ} \mathrm{C}$ (Fig. 1b), which better represented the hydrogel behaviour when injected in the disc at body temperature. $\mathrm{CH}$ gelatine hydrogels presented a rapid increase in $\mathrm{G}^{\prime}$ 
with time at $37^{\circ} \mathrm{C}$. The addition of gelatine decreased the rate in a dose-dependent way, but gelation was rapid for all tested formulations (crossover of storage modulus $\mathrm{G}^{\prime}$ and loss modulus $\mathrm{G}^{\prime \prime}$ in less than $15 \mathrm{~s}$ ).

Interestingly, unconfined compressive properties (Fig. 1c,d) increased significantly in the presence of gelatine. The secant modulus, calculated at $15 \%$ deformation [corresponding to physiological loading conditions (Johannessen et al., 2006)], was significantly higher for the formulations with gelatine compared to control (Fig. 1d) $(p<0.05)$. In addition, failure stress was significantly higher in the presence of gelatine compared to control $(p<0.0001$, $p=0.01$ and $p=0.02$ for $1,1.5$ and $2 \% \mathrm{w} / \mathrm{v}$ gelatine, respectively), with the highest value obtained for $1 \%$ $\mathrm{w} / \mathrm{v}$ gelatine formulation (stress at failure $=99 \pm 6 \mathrm{kPa}$ for control vs. $142 \pm 12 \mathrm{kPa}$ for $1 \% \mathrm{w} / \mathrm{v}$ gelatine). Hydrogel breakage occurred at similar deformation rate for all formulations $(64 \pm 2 \%)$.

\section{Effect of gelatine on the viability and GAG} production of cells encapsulated in $\mathrm{CH}$ hydrogels As shown in Fig. 2, a high cell viability (between 89-92 \%) was observed for all tested formulations at day 1 , indicating no substantial cell death during NP encapsulation. Cell viability remained unchanged until day 14, indicating that gelatine addition did not affect NP cell survival. In fact, the DNA content
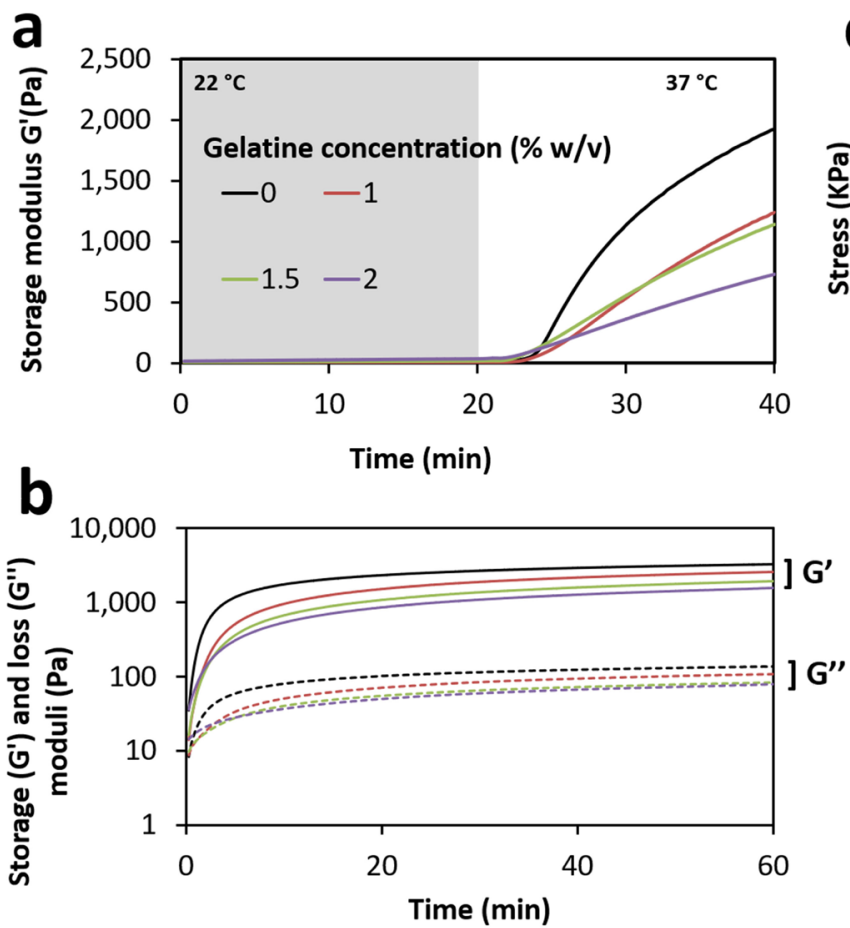

was also similar for all formulations after $14 \mathrm{~d}$ in culture (data not shown). However, NP cells after $14 \mathrm{~d}$ presented a spindle-like shape in $\mathrm{CH}$-gelatine hydrogels, suggesting a better cell-matrix adhesion when compared to $\mathrm{CH}$ hydrogel (Fig. 2).

After $14 \mathrm{~d}$ in normal medium, total GAG synthesis (in the construct and released into the medium) was assessed. The results revealed that the NP cells encapsulated in $\mathrm{CH}$-gelatine hydrogels produced a significantly higher GAG content after $14 \mathrm{~d}$ when compared to the control $(p<0.0001$; Fig. 3a). This increase was observed for all gelatine concentrations. GAG production per DNA (Fig. 3b) was also significantly higher $(p<0.01)$ in the presence of gelatine, suggesting that gelatine increased cell activity.

Based on these results (NP cells responded similarly to all gelatine concentrations, but better mechanical and rheological properties were observed with $1 \%$ gelatine), $1 \% \mathrm{w} / \mathrm{v}$ gelatine was found to be the most appropriate concentration to supplement the $\mathrm{CH}$ hydrogel with. Thus, this formulation $(\mathrm{CH}-1 \%$ gelatine) was selected for all following experiments.

\section{Diffusion of LN within the hydrogel}

To evaluate the effect of LN on encapsulated cells, it is important to first verify that LN would diffuse through the $\mathrm{CH}$ hydrogel. To test this, $\mathrm{CH}$ hydrogel

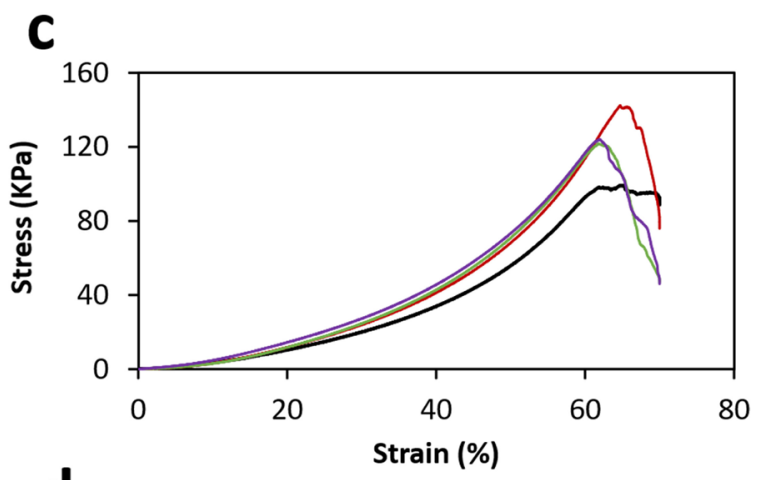

d

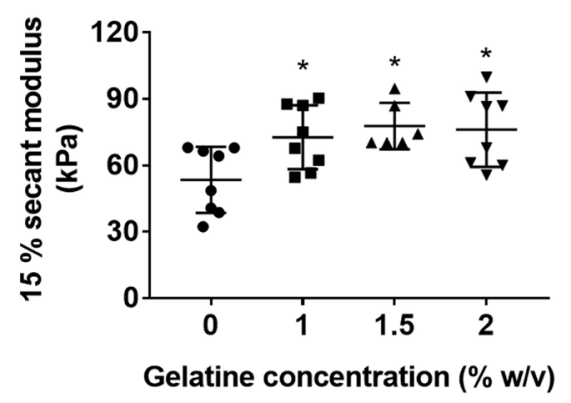

Fig. 1. Effect of gelatine concentration on rheological and unconfined compression properties of $\mathrm{CH}$ hydrogels. $(\mathbf{a}, \mathbf{b})$ Time sweep experiments of $\mathrm{CH}$ hydrogel solutions as a function of gelatine concentration $(0,1,1.5$, and $2 \% \mathrm{w} / \mathrm{v})$. (a) Evolution of storage modulus with time at $22{ }^{\circ} \mathrm{C}$ (to confirm stability at room temperature) followed by temperature increase to $37^{\circ} \mathrm{C}$ (strain $1 \%$, frequency $1 \mathrm{~Hz}$, data shown as mean, $n=3$ ). (b) Evolution of storage modulus with time at $37^{\circ} \mathrm{C}$ (strain $5 \%$, frequency $1 \mathrm{~Hz}$, data shown as mean, $n=3$ ). (c,d) Unconfined compression. (c) Mean stress versus strain curves (up to $70 \%$ of deformation at $100 \% / \mathrm{min}, n=4$ ). (d) Secant modulus of hydrogels at $15 \%$ deformation (mean \pm SD $n=8, * p<0.05$ compared to control). Tests were performed on cylindrical samples (14 $\mathrm{mm}$ diameter, $9 \mathrm{~mm}$ height) left to gel for $24 \mathrm{~h}$ at $37^{\circ} \mathrm{C}$. 
with or without gelatine was incubated in culture medium supplemented with fluorescent LN (with $\mathrm{N}$ terminal 5-FAM). The rapid diffusion of the fluorescent peptide in the gel confirmed that LN rapidly reached the encapsulated cells (Fig. 4). After $24 \mathrm{~h}, \mathrm{LN}$ concentration was close to equilibrium $(71 \mu \mathrm{g} / \mathrm{mL})$ in both $\mathrm{CH}(67 \pm 5 \mu \mathrm{g} / \mathrm{mL})$ and $\mathrm{CH} / 1 \%$ gelatine $(67 \pm 7 \mu \mathrm{g} / \mathrm{mL})$ hydrogels.

Effect of LN on GAG production by cells encapsulated in $\mathrm{CH}$ hydrogel

To evaluate the potential of LN to promote proteoglycan content in hydrogels, NP cells encapsulated in $\mathrm{CH}$ hydrogel (without gelatine) were incubated in either normal medium or degenerative medium, mimicking healthy or degenerated disc environments, respectively. NP cells encapsulated in $\mathrm{CH}$ hydrogel were exposed to 10,25 and $100 \mu \mathrm{g} / \mathrm{mL}$ LN or medium alone for $14 \mathrm{~d}$. GAG production and GAG/DNA ratio were assessed as a function of LN concentration and culture medium (Fig. 5).

As expected, in the degenerative medium, GAG synthesis by NP cells was 3-fold decreased compared with NP cells incubation in normal medium $(p=0.003)$. This significant difference could be explained by the lower cell viability observed in the degenerative (56 $\pm 8 \%$ ) compared to normal medium $(81 \pm 3 \%)$ (data not shown).
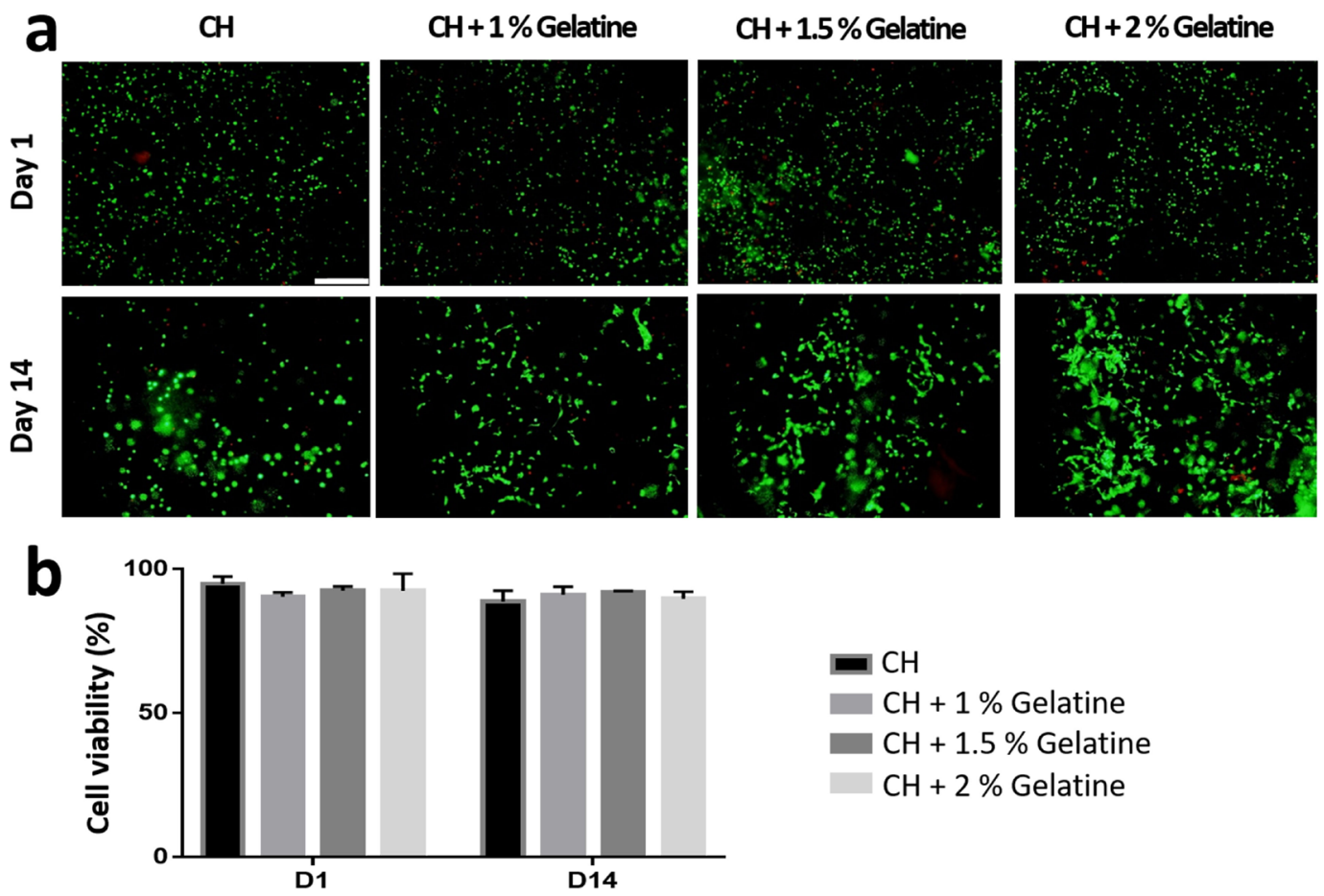

Fig. 2. Viability of NP cells encapsulated in $\mathrm{CH}$ and $\mathrm{CH}$-gelatine hydrogels. (a) Live/dead assay performed after 1 or $14 \mathrm{~d}$ in culture. No significant differences were observed between conditions in terms of cell viability. Scale bar: $300 \mu \mathrm{m}$ (green for living cells and red for dead cells). (b) Percentage of viable cells according to cell counting on LIVE/DEAD ${ }^{\mathrm{TM}}$ images. Data are shown as mean $\pm \mathrm{SD}, n=3$.
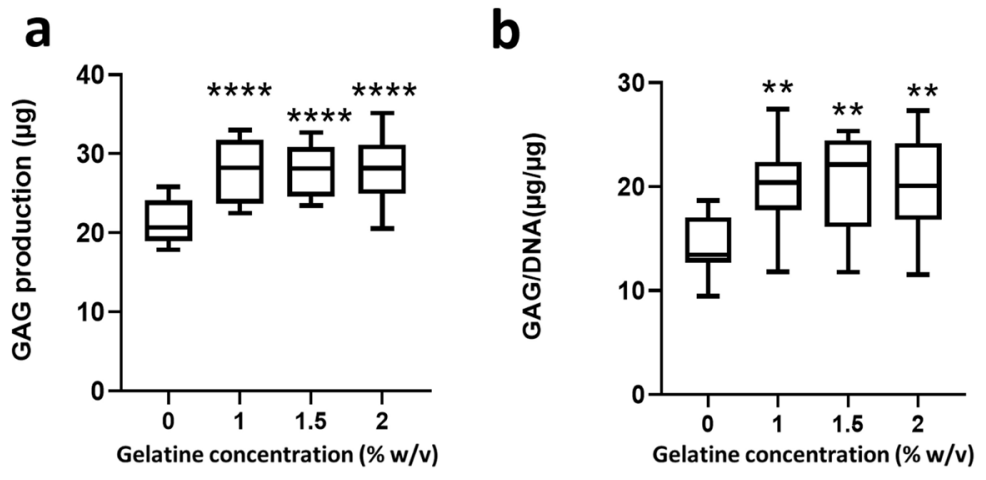

Fig. 3. GAG production by encapsulated NP cells in $\mathrm{CH}$ or in $\mathrm{CH}$-gelatine hydrogels. NP cells were encapsulated in $\mathrm{CH}$ or in $\mathrm{CH}$-gelatine $(1,1.5$ and $2 \% \mathrm{w} / \mathrm{v})$ hydrogels and cultured in normal medium for $14 \mathrm{~d}$. (a) Total GAG production (in construct and released into the medium) was analysed by DMMB assay. (b) GAG production was normalised to DNA quantity (measured by PicoGreen ${ }^{\circledR}$ assay; $n=12-14$, $\left.* * * * p<0.0001,{ }^{* *} p<0.01\right)$. 
LN did not elicit any significant effect on GAG content when constructs were cultured in normal medium (Fig. 5a,c). However, when cells were cultured in degenerative medium, the results were strikingly different, showing a statistically significant dose-dependent increase in proteoglycan content in response to LN supplementation, with maximal response at the highest dose of LN $(p<0.0001)$ (Fig. $5 \mathbf{b}, \mathbf{d})$. Thus, when the degenerative medium was supplemented with $25 \mu \mathrm{g} / \mathrm{mL}$ and $100 \mu \mathrm{g} / \mathrm{mL} \mathrm{LN}$, GAG synthesis was increased by 3.1-fold and 4.7-fold, respectively, compared to the degenerative medium alone (Fig. 5b), reaching similar or higher levels of GAG synthesis compared to normal conditions. DNA content was similar for all LN concentrations (data not shown), suggesting that the increase in GAG production was due to increased cell activity, not cell proliferation. Indeed, similar trends were obtained when GAG production was normalised to DNA content (3.3-fold and 4.6-fold superior to the control) (Fig. 5d). However, no difference was observed at the low dose of $\mathrm{LN}(10 \mu \mathrm{g} / \mathrm{mL})$.

Additive effect of LN and gelatine on GAG production in normal and degenerative environment To determine the additive benefit of gelatine and LN on GAG production, NP cells encapsulated in $\mathrm{CH}$ or $\mathrm{CH}-1 \%$ gelatine hydrogels were cultured for $14 \mathrm{~d}$ in the normal or degenerative medium supplemented with $100 \mu \mathrm{g} / \mathrm{mL} \mathrm{LN}$ or $50 \mathrm{ng} / \mathrm{mL}$ TGF- $\beta 1$ (Fig. 6). TGF- $\beta$ was used as a positive control due to its confirmed role in promoting GAG production (Smith et al., 2014).

Notwithstanding the medium used, TGF- $\beta$ significantly increased GAG synthesis in NP cells $(p<0.0001)$ compared to the control (Fig. 6a,b). GAG production in the presence of TGF- $\beta$ was significantly more in $\mathrm{CH}-1$ \% gelatine compared to $\mathrm{CH}$ hydrogel,

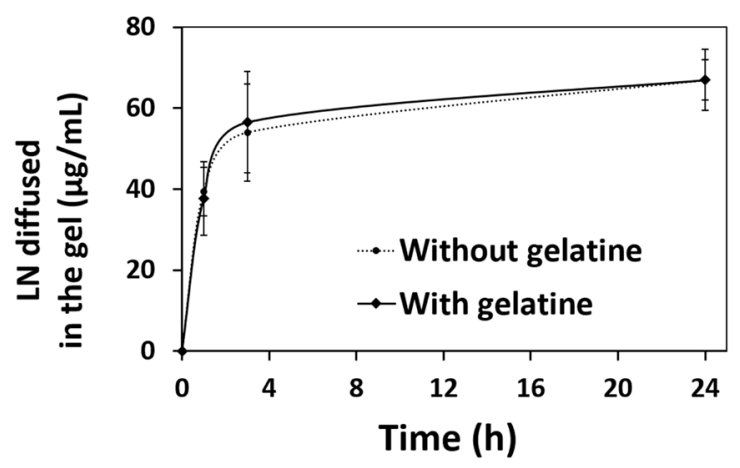

Fig. 4. $\mathrm{LN}$ diffusion within the $\mathrm{CH}$ and $\mathrm{CH}-1 \%$ gelatine hydrogels. 5-FAM-conjugated LN was placed on top of the $\mathrm{CH}$ hydrogels with or without gelatine. The medium was retrieved and analysed spectrophotometrically to quantify the remaining LN in the medium at each time point. This amount was subtracted from the initial LN content to assess the amount of LN that diffused into the gel. LN concentration in the gel after 1,3 and $24 \mathrm{~h}$ are shown as mean $\pm \mathrm{SD}, n=4-6$. in both normal (Fig. 6a, $p=0.02$ ) and degenerative medium (Fig. $6 \mathbf{b}, p<0.0001$ ), suggesting a potential additive effect of TGF- $\beta$ and gelatine on NP cell activity. However, GAG synthesis in the presence of TGF- $\beta$ was reduced in the degenerative compared to normal medium by over $41 \%$ and $30 \%$ in the $\mathrm{CH}$ and $\mathrm{CH}-1 \%$ gelatine hydrogels, respectively.

GAG concentrations in constructs cultured in normal medium supplemented with LN were similar to that in controls (Fig. 6a). In contrast, a significant increase was observed when incubated in degenerative medium $(p<0.0001$ for $\mathrm{LN}$ without gelatine; $p=0.003$ for LN with gelatine; Fig. $6 \mathbf{b}$ ). Since there was no difference in DNA content between conditions after $14 \mathrm{~d}$ (data not shown), a similar trend was observed for GAG production per DNA (Fig. $6 c, d)$. Interestingly, in degenerative medium, GAG production in the presence of LN was more than in normal medium ( $p=0.0007$ for $\mathrm{CH}$ and $\mathrm{CH}-1 \%$ gelatine hydrogels) and reached similar levels to that in the presence of TGF- $\beta$. Gelatine addition to the hydrogel tended to further increase GAG production. This difference was significant in the degenerative ( $p=0.03$ ) but not in normal medium. The observations were similar when analysing GAG production per DNA (GAG/DNA) in normal (Fig. 6c) and degenerative media (Fig. 6d). This indicated that in early disc degeneration, LN alone has the potential to restore proteoglycan content and that an additional benefit is achieved by including gelatine in the construct.

\section{Cell viability of encapsulated NP cells supplemented with either LN or TGF- $\beta$}

To verify that supplementation of $50 \mathrm{ng} / \mathrm{mL}$ TGF- $\beta$ or $100 \mu \mathrm{g} / \mathrm{mL} \mathrm{LN}$ in a normal or degenerative medium was not detrimental to the cells, cell viability was assessed. Cell viability was maintained at $>80 \%$ when NP cells were encapsulated in $\mathrm{CH}$ or $\mathrm{CH}-1 \%$ gelatine hydrogels supplemented with either $\mathrm{LN}$ or TGF- $\beta$ in normal conditions after $14 \mathrm{~d}$, In contrast, at day 14 (Fig. 7), the incubation in degenerative medium induced relatively high cellular death (52 $\pm 11 \%$ viability) in $\mathrm{CH}$ hydrogel, indicating that the medium used in these studies mimicked the degenerative disc environment where cell death is commonly observed (Trout et al., 1982). However, $\mathrm{CH}-1$ \% gelatine hydrogels incubated in the degenerative medium supplemented with LN $(76 \pm 11 \%)$ showed greater cell viability compared to TGF- $\beta$ and control (50 $\pm 12 \%$ ), suggesting that LN may have a protective effect against cell death in the presence of gelatine.

\section{Discussion}

To the authors' knowledge, this was the first study evaluating an injectable therapy for IVD repair in conditions simulating the degenerative disc microenvironment. A thermosensitive injectable 
$\mathrm{CH}$ hydrogel was previously developed, showing adequate mechanical properties and cell survival for IVD repair but a suboptimal synthesis of proteoglycans (Alinejad et al., 2019). Since the loss of proteoglycans is one of the most notable changes in IVD degeneration, the primary goal of this investigation was to evaluate the potential of LN and gelatine to increase proteoglycan production by encapsulated NP cells in CH hydrogels, in a degenerative IVD microenvironment.

Data indicated that $\mathrm{CH}$ hydrogel supplemented with $1 \% \mathrm{w} / \mathrm{v}$ gelatine increased significantly GAG production by NP cells while showing adequate gelation profile and a significant increase in compressive mechanical properties. Gelatine has been already used by several researchers in combination with $\mathrm{CH}$ to form 2D membranes or 3D scaffolds for tissue engineering. It has been used either to form polyelectrolytes with $\mathrm{CH}$ (Huang et al., 2005; Mao et al., 2003; Ng et al., 2016) or to reinforce CH-BGP gels with limited mechanical properties (Cheng et al., 2010). Cheng et al. (2010) showed that $1 \% \mathrm{w} / \mathrm{v}$ gelatine decreases the gelation time of $\mathrm{CH}-$ BGP gels from more than 10 min to less than $1 \mathrm{~min}$ and increases their storage modulus from $<10 \mathrm{~Pa}$ to $\sim 500 \mathrm{~Pa}$ after $10 \mathrm{~min}$ at $37^{\circ} \mathrm{C}$. In the present study, $\mathrm{CH}$ was mixed with SHC and BGP as gelling agents, to increase drastically the mechanical properties and shorten gelation time, while allowing for better cytocompatibility due to the lower BGP content (Ceccaldi et al., 2017). As expected, results confirmed larger $\mathrm{G}^{\prime}$ values at $10 \mathrm{~min}(1,700$ and 1,300 Pa for $\mathrm{CH}$ and $\mathrm{CH}-1 \%$ gelatine, respectively) and a shorter gelation time for all $\mathrm{CH}$-gelatine formulations $(<15 \mathrm{~s}$ at $37^{\circ} \mathrm{C}$ ). Results were also in agreement with Cheng et al. (2010) with respect to increased mechanical properties in the presence of gelatine. However, gelatine tended to reduce the gelation rate (as shown by slower increase in $\mathrm{G}^{\prime}$ and lower $\mathrm{G}^{\prime}$ after $1 \mathrm{~h}$ at $\left.37^{\circ} \mathrm{C}\right)$. This result may be explained by gelatine charge. Indeed, at physiological $\mathrm{pH}$, both gelatine type $\mathrm{A}$ and $\mathrm{CH}$ molecules are positively charged (Van Vlierberghe et al., 2014). The mechanism of CH thermogelation is related to $\mathrm{CH}$ chain's neutralisation by BGP and SHC, followed by proton transfer when increasing the temperature (Lavertu et al., 2008). The presence of positively charged gelatine in the solution may have reduced the degree of neutralisation of $\mathrm{CH}$ chains and delay the proton transfer to the base. This may explain why after $1 \mathrm{~h}$ the viscoelastic properties of $\mathrm{CH}$-gelatine hydrogels were lower than those of $\mathrm{CH}$ hydrogel. However, the compressive properties of $\mathrm{CH}$-gelatine hydrogels after $24 \mathrm{~h}$ gelation were improved, especially the mechanical strength, which
Normal medium

\section{a}

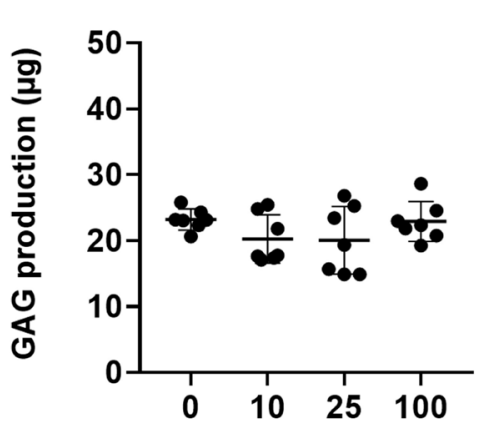

\section{Degenerative medium}

b
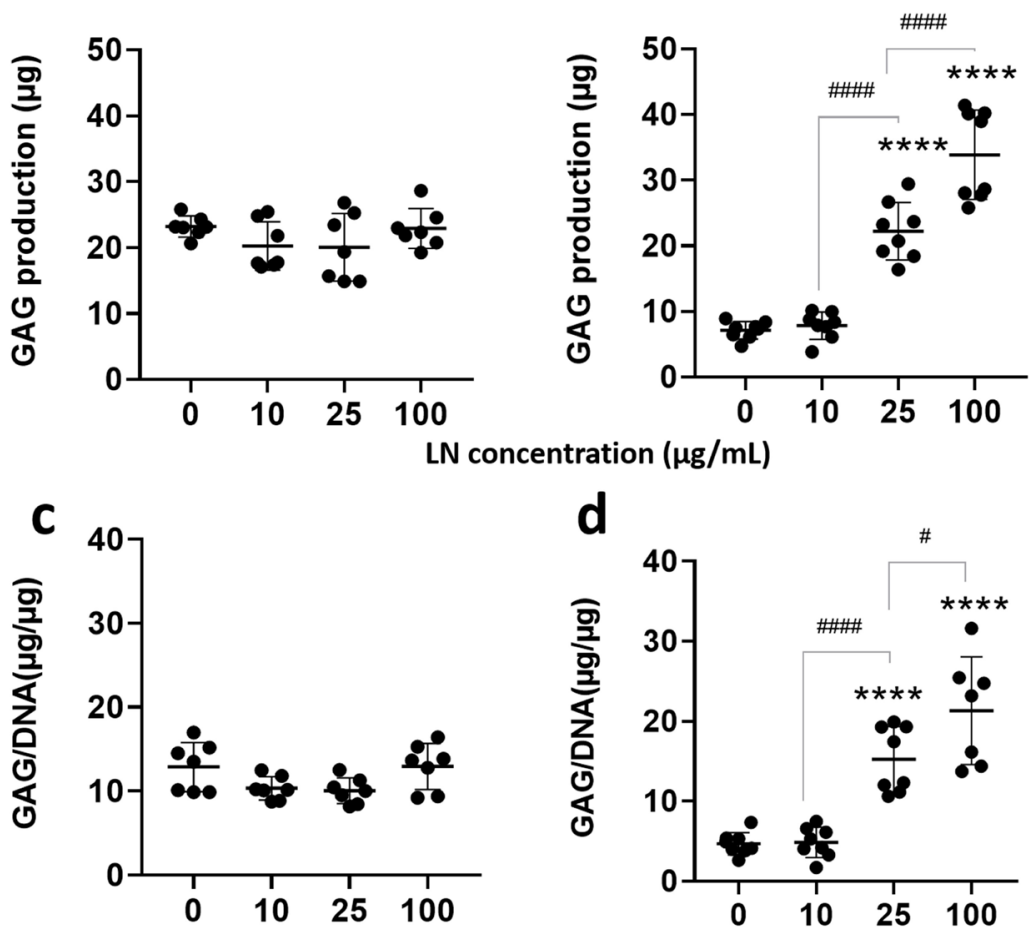

d

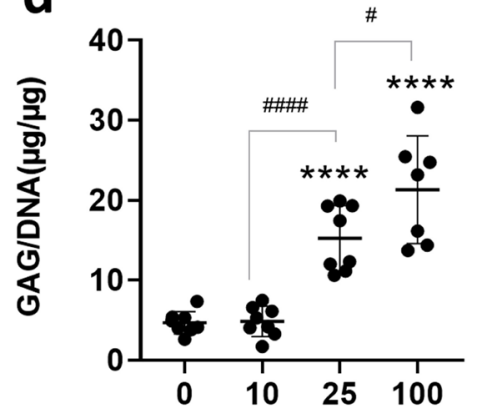

$\mathrm{LN}$ concentration $(\mu \mathrm{g} / \mathrm{mL})$

Fig. 5. Proteoglycan (GAG) production by encapsulated NP cells treated with LN. Bovine NP cells were encapsulated in $\mathrm{CH}$ hydrogels and cultured in either normal or degenerative medium in the presence of LN $(10,25$ and $100 \mu \mathrm{g} / \mathrm{mL}$ ) or medium without peptide supplementation for $14 \mathrm{~d}$. GAG content was taken as a measurement of proteoglycan. Total GAG production per construct in (a) normal and (b) degenerative media. GAG production per $1 \mu \mathrm{g}$ DNA in (c) normal and (d) degenerative media. Data are expressed as mean \pm SD, one-way ANOVA followed by Tukey post-hoc test, $n=7 ;{ }^{* * *} p<0.0001$ (compared to control). 
increased from 99 to $142 \mathrm{kPa}$ (with $1 \%$ gelatine). Gelatine chains are able to form hydrogen bonds when mixed together (Cheng et al., 2003; Ng et al., 2016). Thus, gelatine addition may have transformed $\mathrm{CH}$ hydrogel from a simple physical hydrogel network to a reinforced IPN (Karak, 2012). Alinejad et al. (2019) showed that $\mathrm{CH}$ hydrogel presents compressive properties very similar to human NP. In the present study, the rigidity in compression was slightly increased by the addition of gelatine, but remained in the same range, which allowed us to conclude that the $\mathrm{CH}$-gelatine hydrogels also presented compressive properties close to human NP.

In addition to this mechanical benefit, gelatine induced more GAG production by encapsulated NP cells. As shown in the live/dead images, $\mathrm{CH}$ hydrogels supplemented with gelatine increased NP cells adhesion to the scaffold. Indeed, gelatine provides amino acid sequences similar to collagen to help facilitate cell adhesion (Huang et al., 2005; Zheng et al., 2018), which can stimulate GAG production. Besides, through some structural changes in the hydrogel, gelatine may have increased the amount of nutrient and oxygen inside the gel, which can be also translated into an increase in GAG production (Xia et al., 2004).
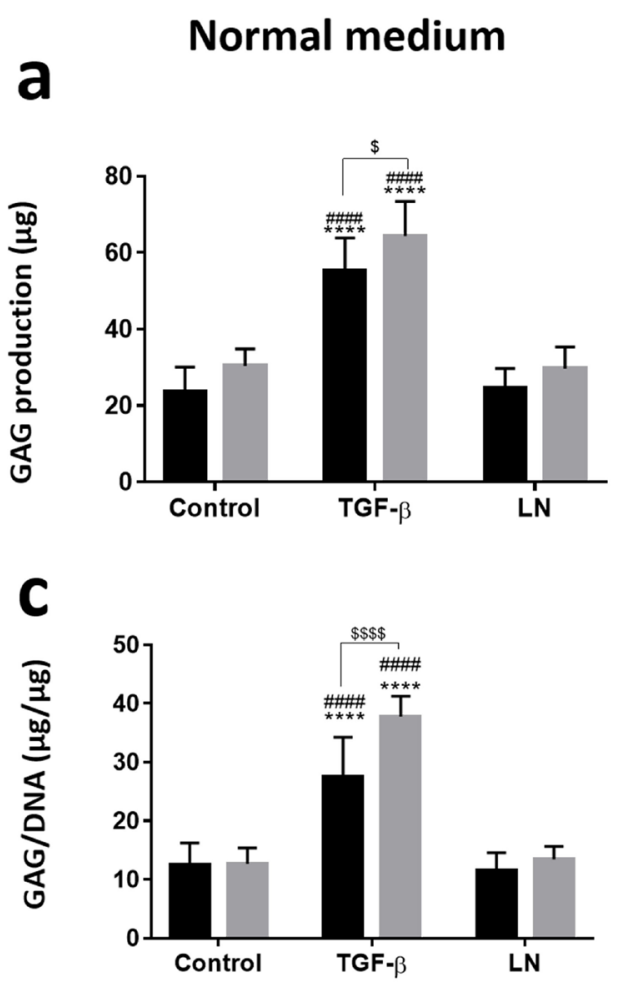

TGF- $\beta$ is among the several growth factors, including GDF-5 and OP-1, that have been previously investigated and showed promising results in restoring proteoglycan content and stimulating new disc matrix formation (Masuda and An, 2004). Although these strategies have reached animal studies and been approached in the clinic (Web ref. 2 ), some may have delayed or reduced pain, but none have achieved biological repair of a diseased IVD (Hodgkinson et al., 2019). TGF- $\beta$ is one of the most potent growth factors for promoting matrix production. Activation of TGF- $\beta$ plays a critical role in mechanical signalling transduction to regulate IVD cell function and homeostasis (Bian et al., 2017). TGF- $\beta$ can increase GAG production through increased mRNA expression and inhibition of proteases that induce ECM protein degradation (Bassols and Massague, 1988; Roberts et al., 1992). However, TGF- $\beta$ is not suitable for clinical applications due to its tumorigenicity (Brahmkhatri et al., 2015) and high cost. It was used in the present study only as a positive control.

Compared to other growth factors, known for their involvement in osteogenesis and unwanted and uncontrolled side effects (Lebrun, 2012), LN action is specific to chondrogenic tissues such as IVD and

b

\section{Degenerative medium}

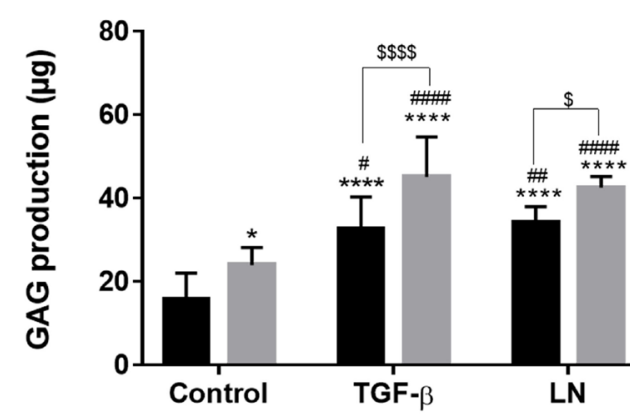

d

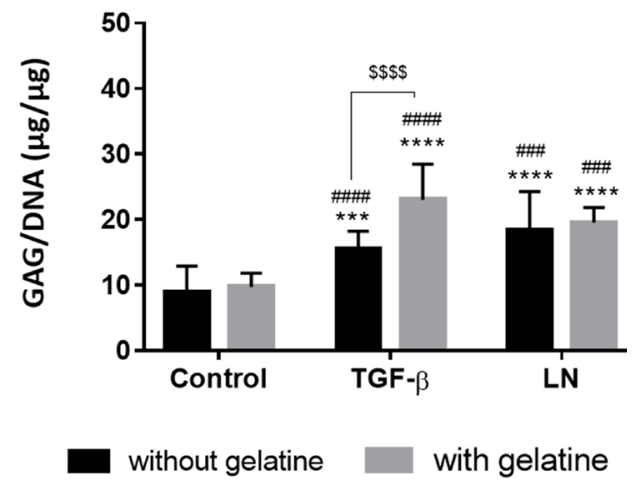

Fig. 6. Proteoglycan production by encapsulated NP treated with either LN or TGF- $\beta$. NP cells were seeded in $\mathrm{CH}$ or $\mathrm{CH}-1$ \% gelatine hydrogel and cultured in $(\mathbf{a}, \mathbf{c})$ normal or $(\mathbf{b}, \mathbf{d})$ degenerative media in the presence of $100 \mu \mathrm{g} / \mathrm{mL} \mathrm{LN}, 50 \mathrm{ng} / \mathrm{mL}$ TGF- $\beta$ or medium without peptide supplementation for $14 \mathrm{~d}$. GAG content was taken as a measurement of proteoglycan. Data shown as mean \pm SD, two-way ANOVA followed by Tukey post-hoc comparison $\left({ }^{*} p<0.05\right.$, ${ }^{* * * *} p<0.0001$ compared to control without gelatine, $\#^{\# \#} p<0.001,{ }^{\# \# \#} p<0.0001$ compared to control with gelatine, $\left.{ }^{\$} p<0.05,,^{\$ \$} p<0.001,{ }^{\$ \$ \$} p<0.0001, n=8-16\right)$. 
cartilage (Mwale et al., 2014). Previous studies have demonstrated that $\mathrm{LN}$ acts as an anabolic agent in the IVD, increasing the expression and synthesis of structural matrix proteins and reversing the structural deterioration (Antoniou et al., 2012; Bach et al., 2017; Gawri et al., 2012; Mwale et al., 2011). It inhibits both the expression of pro-inflammatory cytokines and pain-associated factors (Noorwali et al., 2018), and the co-administration of MSCs and LN synergistically enhances the repair of IVDs in a disc degeneration model (Mwale et al., 2014). Therefore, LN meets the criteria for an ideal IVDD treatment, reversing structural degradation of the IVD and blocking the inflammatory and pain-producing pathways.

Most of the studies testing the effect of bioactive agents on NP cells were conducted either in chemically controlled medium (Smith et al., 2014) or medium simulating normal culture conditions (Gawri et al., 2012; Masuda, 2008; Miyamoto et al., 2006). In fact, the IVD represents a very harsh microenvironment even in its healthy state (low oxygen levels, high osmolarity, nutritional deficits and high mechanical loading). During degeneration, these conditions are further aggravated by numerous factors such as nutritional deficits, increased matrix acidity and inflammation, which can affect cell survival, behaviour and ECM production. The degenerative medium used in the present study, by composition, mimicked closely the degenerative IVD environment. The medium had a lower $\mathrm{pH}$ and osmolarity and a selectively higher mineral content, including supplementation with the inflammatory cytokine IL-1 $\beta$, representing the conditions of a degenerative disc (van Dijk et al., 2011), which was targeted by the present therapy.

Data indicated that, under conditions mimicking the degenerative disc environment, LN induced a strong increase in GAG production by NP cells. a
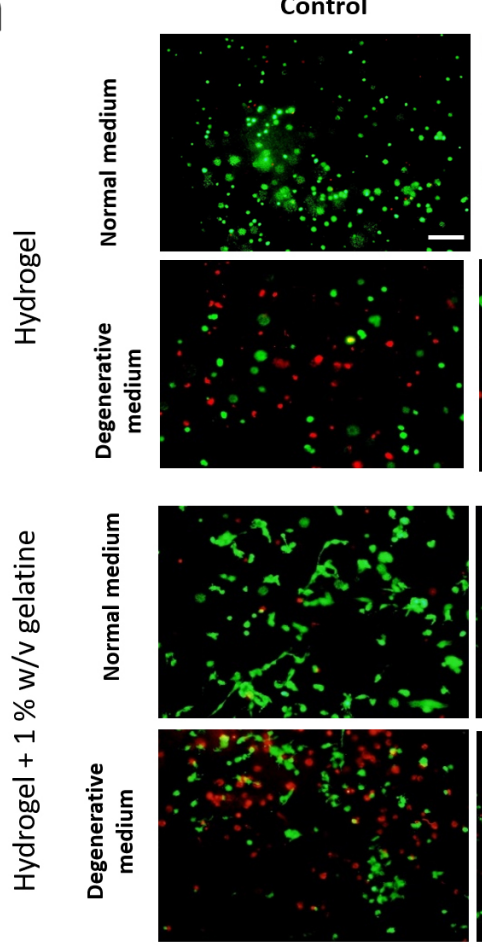

b
$50 \mathrm{ng} / \mathrm{mL}$ TGF- $\beta$
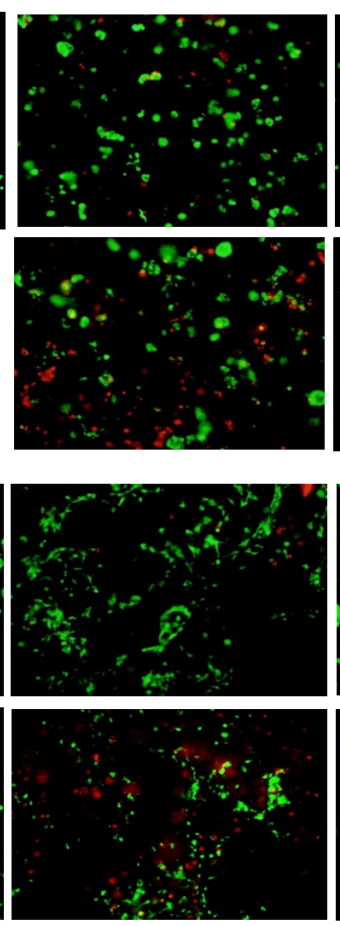

c
$100 \mu \mathrm{g} / \mathrm{mL} \mathrm{LN}$
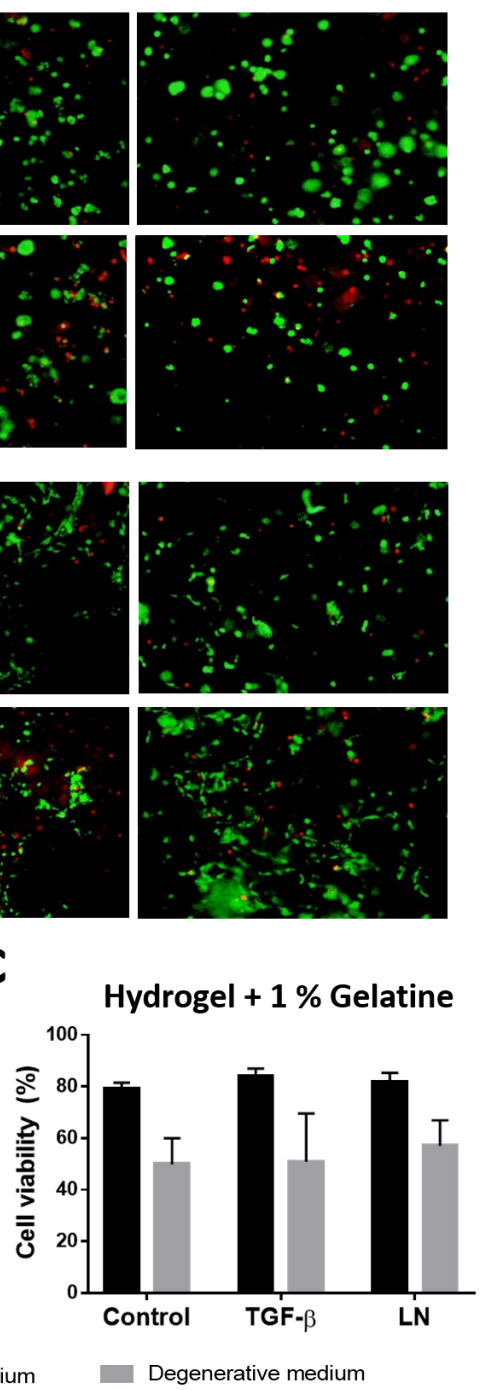

Fig. 7. Effect of LN or TGF- $\beta$ supplementation on bovine NP cell viability encapsulated in $\mathrm{CH}$ or $\mathrm{CH}-1 \%$ gelatine scaffolds. (a) LIVE/DEAD ${ }^{\mathrm{TM}}$ assay performed at $14 \mathrm{~d}$ on NP cells encapsulated in hydrogel with or without gelatine in normal and degenerative medium alone (control), supplemented with $50 \mathrm{ng} / \mathrm{mL}$ TGF- $\beta$ or $100 \mu \mathrm{g} / \mathrm{mL}$ LN. Scale bar: $200 \mu \mathrm{m}$. Green for living cells and red for dead cells. (b,c) Percentage of viable cells according to cell counting on LIVE/DEAD ${ }^{\mathrm{TM}}$ images. Data are shown as mean $\pm \mathrm{SD}, n=3$, two-way ANOVA followed by Tukey post-hoc comparison. ${ }^{*} p<0.05,{ }^{* *} p<0.01,{ }^{* * *} p<0.001$. 
This finding was in an agreement with earlier data (Alaqeel et al., 2020) showing that LN can restore GAG production to healthy control levels in human osteoarthritic cartilage when exposed to IL-1 $\beta$, an inflammatory cytokine known for its catabolic activities in cartilage and IVD (Masuda and An, 2004; Yang et al., 2015). The strong effect of LN observed in these conditions could be partly explained by the fact that LN inhibits IL-1 $\beta$ signalling pathways (Alaqeel et al., 2020). Interestingly, the study's findings demonstrated that in a degenerative medium, the level of GAG achieved with LN reached similar levels to those observed with TGF- $\beta$. However, LN did not stimulate GAG production in normal medium. Previous work has also demonstrated that LN has no apparent effect in the medial tibial plateau of a rabbit model of osteoarthritis (Antoniou et al., 2019). The authors reported that this may be related to the low-grade of cartilage pathology occurring at this site in the model. This observation raises the possibility that LN exerts its influence once matrix degradation exceeds turnover (Alaqeel et al., 2020; Antoniou et al., 2019). In contrast, TGF- $\beta$ increased GAG production in both normal and degenerative conditions.

Interestingly, NP cell survival appeared to be stimulated by LN in the presence of gelatine in degenerative medium. In contrast, supplementation with TGF- $\beta$ did not affect cell viability in a similar manner. Antoniou et al. (2019) demonstrated that LN has chondroprotective properties that may have been enhanced in the presence of gelatine, protecting NP cells against the harmful composition of the degenerative medium. Furthermore, in a degenerative environment, $\mathrm{LN}$ and gelatine induced more GAG production compared to $\mathrm{LN}$ and gelatine used separately, suggesting an independent additive benefit. This could be explained by the fact that LN and gelatine do not affect the cells in the same manner. Gelatine improves GAG production by inducing a change in cell adhesion and organisation while LN improves GAG synthesis through stimulation of Sox 9 expression and inhibition of inflammatory protein (Antoniou et al., 2012).

Despite the significant benefit of gelatine and LN, the amount of synthetised GAG was still lower $(10 \%)$ than in healthy human disc (Alini et al., 2003). In further work, a prolonged incubation time, an increase in cells density in the gel and a mechanical stimulation during the culture may help increase GAG production close to in vivo levels.

The present study established the proof-ofconcept that $\mathrm{LN}$ embedded in $\mathrm{CH}$ or $\mathrm{CH}$-gelatine scaffolds could increase the activity of encapsulated cells. Further investigations are required to define how exactly LN should be incorporated in the gel for clinical transfer. The first strategy may be to add $\mathrm{LN}$ in the cell suspension before encapsulation. Then, rapid diffusion of $\mathrm{LN}$ is expected but should not be an issue in vivo since the released LN will stay in the disc and may stimulate native disc cells surrounding the injected scaffold. Another option may be to embed
LN in nanoparticles before encapsulation to better control the release profile.

This study was performed with NP cells to determine the effectiveness of the technology. Next, ex vivo and in vivo steps will be performed to validate the findings in a clinically available cell source such as human stem cells, to facilitate the translation of the technology.

\section{Conclusions}

LN and gelatine were evaluated as bioactive agents in order to establish whether they were capable of increasing the viability and activity of NP cells encapsulated in 3D CH thermosensitive hydrogels. LN increased GAG production in a degenerative medium to the same level as TGF- $\beta$. Addition of $1 \%$ gelatine in a $\mathrm{CH}$ hydrogel further increased GAG production and interestingly improved the mechanical resistance of a $\mathrm{CH}$ hydrogel, whose elasticity was similar to native NP tissue. The results supported the concept that a $\mathrm{CH}$ hydrogel supplemented with LN and gelatine may be an ideal scaffold for cell-based supplementation to help enhance the function of the NP during the early stages of IVD degeneration.

\section{Acknowledgements}

The authors would like to thank funding organisations CIHR and NSERC (Collaborative Health Research Program 508365) as well as Canada research chair program (S.L.). A.A. also acknowledges scholarships by NSERC.

All authors have no financial or non-financial conflicts of interest to disclose.

\section{References}

Alaqeel M, Grant M, Epure L, Salem O, AlShaer A, Huk O, Bergeron S, Zukor D, Kc R, Im H (2020) Link $N$ suppresses interleukin-1 $\beta$-induced biological effects on human osteoarthritic cartilage. Eur Cell Mater 39: 65-76.

Alinejad Y, Adoungotchodo A, Grant MP, Epure LM, Antoniou J, Mwale F, Lerouge S (2019) Injectable chitosan hydrogels with enhanced mechanical properties for nucleus pulposus regeneration. Tissue Eng Part A 25: 303-313.

Alini M, Li W, Markovic P, Aebi M, Spiro RC, Roughley PJ (2003) The potential and limitations of a cell-seeded collagen/hyaluronan scaffold to engineer an intervertebral disc-like matrix. Spine (Phila Pa 1976) 28: 446-454.

Antoniou J, Epure L, Grant M, Richard H, Sampalis J, Roughley P, Laverty S, Mwale F (2019) Short link $\mathrm{N}$ acts as a disease modifying osteoarthritis drug. Eur Cell Mater 37: 347-359. 
Antoniou J, Wang HT, Alaseem AM, Haglund L, Roughley PJ, Mwale F (2012) The effect of Link N on differentiation of human bone marrow-derived mesenchymal stem cells. Arthritis Res Ther 14: R267. DOI: 10.1186/ar4113.

Assaad E, Maire M, Lerouge S (2015) Injectable thermosensitive chitosan hydrogels with controlled gelation kinetics and enhanced mechanical resistance. Carbohydr Polym 130: 87-96.

Bach FC, Laagland LT, Grant MP, Creemers LB, Ito K, Meij BP, Mwale F, Tryfonidou MA (2017) Link-N: the missing link towards intervertebral disc repair is species-specific. PLoS One 12: e0187831. DOI: 10.1371/ journal.pone.0187831.

Bassols A, Massague J (1988) Transforming growth factor beta regulates the expression and structure of extracellular matrix chondroitin/dermatan sulfate proteoglycans. J Biol Chem 263: 3039-3045.

Bian Q, Ma L, Jain A, Crane JL, Kebaish K, Wan M, Zhang Z, Edward Guo X, Sponseller PD, Séguin CA, Riley LH, Wang Y, Cao X (2017) Mechanosignaling activation of TGF $\beta$ maintains intervertebral disc homeostasis. Bone Res 5: 17008. DOI: 10.1038/ boneres.2017.8.

Brahmkhatri VP, Prasanna C, Atreya HS (2015) Insulin-like growth factor system in cancer: novel targeted therapies. Biomed Res Int 2015: 538019538019.

Ceccaldi C, Assaad E, Hui E, Buccionyte M, Adoungotchodo A, Lerouge S (2017) Optimization of injectable thermosensitive scaffolds with enhanced mechanical properties for cell therapy. Macromol Biosci 17. DOI: 10.1002/mabi.20160043.

Cheng M, Deng J, Yang F, Gong Y, Zhao N, Zhang $X$ (2003) Study on physical properties and nerve cell affinity of composite films from chitosan and gelatine solutions. Biomaterials 24: 2871-2880.

Cheng Y-H, Yang S-H, Su W-Y, Chen Y-C, Yang K-C, Cheng WT-K, Wu S-C, Lin F-H (2010) Thermosensitive chitosan-gelatine-glycerol phosphate hydrogels as a cell carrier for nucleus pulposus regeneration: an in vitro study. Tissue Eng Part A 16: 695-703.

Freemont A (2009) The cellular pathobiology of the degenerate intervertebral disc and discogenic back pain. Rheumatology (Oxford) 48: 5-10.

Frith JE, Cameron AR, Menzies DJ, Ghosh P, Whitehead DL, Gronthos S, Zannettino ACW, Cooper-White JJ (2013) An injectable hydrogel incorporating mesenchymal precursor cells and pentosan polysulphate for intervertebral disc regeneration. Biomaterials 34: 9430-9440.

Garnjanagoonchorn W, Wongekalak L, Engkagul A (2007) Determination of chondroitin sulfate from different sources of cartilage. Chemical Engineering and Processing: Process Intensification 46: 465-471.

Gawri R, Antoniou J, Ouellet J, Awwad W, Steffen T, Roughley P, Haglund L, Mwale F (2012) Best paper NASS 2013: link-N can stimulate proteoglycan synthesis in the degenerated human intervertebral discs. Eur Cell Mater 26: 107-119.
Gawri R, Ouellet J, Önnerfjord P, Alkhatib B, Steffen $\mathrm{T}$, Heinegård $\mathrm{D}$, Roughley $\mathrm{P}$, Antoniou J, Mwale F, Haglund L (2014) Link N is cleaved by human annulus fibrosus cells generating a fragment with retained biological activity. J Orthop Res 32: 1189-1197.

Gentile P, Nandagiri VK, Daly J, Chiono V, Mattu C, Tonda-Turo C, Ciardelli G, Ramtoola Z (2016) Localised controlled release of simvastatin from porous chitosan-gelatine scaffolds engrafted with simvastatin loaded PLGA-microparticles for bone tissue engineering application. Mater Sci Eng C Mater Biol Appl 59: 249-257.

Gilchrist CL, Chen J, Richardson WJ, Loeser RF, Setton LA (2007) Functional integrin subunits regulating cell-matrix interactions in the intervertebral disc. J Orthop Res 25: 829-840.

Gilchrist CL, Darling EM, Chen J, Setton LA (2011) Extracellular matrix ligand and stiffness modulate immature nucleus pulposus cell-cell interactions. PLoS One 6: e27170. DOI: 10.1371/journal.pone.0027170.

Hodgkinson T, Shen B, Diwan A, Hoyland JA, Richardson SM (2019) Therapeutic potential of growth differentiation factors in the treatment of degenerative disc diseases. JOR Spine 2: e1045. DOI: 10.1002/jsp2.1045.

Huang Y, Onyeri S, Siewe M, Moshfeghian A, Madihally SV (2005) In vitro characterization of chitosan-gelatine scaffolds for tissue engineering. Biomaterials 26: 7616-7627.

Iatridis JC, Nicoll SB, Michalek AJ, Walter BA, Gupta MS (2013) Role of biomechanics in intervertebral disc degeneration and regenerative therapies: what needs repairing in the disc and what are promising biomaterials for its repair? Spine J 13: 243-262.

Jaipan P, Nguyen A, Narayan RJ (2017) Gelatinebased hydrogels for biomedical applications. MRS Commun 7: 416-426.

Johannessen W, Auerbach JD, Wheaton AJ, Kurji A, Borthakur A, Reddy R, Elliott DM (2006) Assessment of human disc degeneration and proteoglycan content using T1Q-weighted magnetic resonance imaging. (Phila Pa 1976) 31: 1253-1257.

Karak N (2012) Fundamentals of polymers. In: Vegetable oil-based polymers. Woodhead Publishing, pp: 1-30.

Kim DJ, Moon SH, Kim H, Kwon UH, Park MS, Han KJ, Hahn SB, Lee HM (2003) Bone morphogenetic protein-2 facilitates expression of chondrogenic, not osteogenic, phenotype of human intervertebral disc cells. Spine (Phila Pa 1976) 28: 2679-2684.

Lavertu M, Filion D, Buschmann MD (2008) Heat-induced transfer of protons from chitosan to glycerol phosphate produces chitosan precipitation and gelation. Biomacromolecules 9: 640-650.

Lebrun J-J (2012) The dual role of TGF $\beta$ in human cancer: from tumor suppression to cancer metastasis. ISRN Mol Biol 2012: 381428-381428.

Lee BH, Shirahama H, Cho N-J, Tan LP (2015) Efficient and controllable synthesis of highly 
substituted gelatine methacrylamide for mechanically stiff hydrogels. RSC Advances 5: 106094-106097.

Liang $\mathrm{HC}$, Chang $\mathrm{WH}$, Liang $\mathrm{HF}$, Lee $\mathrm{MH}$, Sung HW (2004) Crosslinking structures of gelatin hydrogels crosslinked with genipin or a water-soluble carbodiimide. J Appl Polym Sci 91: 4017-4026.

Mao JS, Zhao LG, Yin YJ, Yao KD (2003) Structure and properties of bilayer chitosan-gelatin scaffolds. Biomaterials 24: 1067-1074.

Masuda K (2008) Biological repair of the degenerated intervertebral disc by the injection of growth factors. Eur Spine J 17: 441. DOI: 10.1007/ s00586-008-0749-z.

Masuda K, An HS (2004) Growth factors and the intervertebral disc. Spine J 4: 330S-340S.

Melching L, Roughley P (1985) The role of link protein in mediating the interaction between hyaluronic acid and newly secreted proteoglycan subunits from adult human articular cartilage. J Biol Chem 260: 16279-16285.

Miyamoto K, Masuda K, Kim JG, Inoue N, Akeda $\mathrm{K}$, Andersson GB, An HS (2006) Intradiscal injections of osteogenic protein-1 restore the viscoelastic properties of degenerated intervertebral discs. Spine J 6: 692-703.

Mwale F, Masuda K, Pichika R, Epure LM, Yoshikawa T, Hemmad A, Roughley PJ, Antoniou J (2011) The efficacy of Link $N$ as a mediator of repair in a rabbit model of intervertebral disc degeneration. Arthritis Res Ther 13: R120. DOI: 10.1186/ar3423.

Mwale F, Wang HT, Roughley P, Antoniou J, Haglund L (2014) Link N and mesenchymal stem cells can induce regeneration of the early degenerate intervertebral disc. Tissue Eng Part A 20: 2942-2949.

NgWL, Yeong WY, Naing MW (2016) Development of polyelectrolyte chitosan-gelatin hydrogels for skin bioprinting. Procedia CIRP 49: 105-112.

Nguyen TH, Randolph DC, Talmage J, Succop P, Travis R (2011) Long-term outcomes of lumbar fusion among workers' compensation subjects: a historical cohort study. Spine (Phila Pa 1976) 36: 320-331.

Noorwali H, Grant MP, Epure LM, Madiraju P, Sampen H-J, Antoniou J, Mwale F (2018) Link N as a therapeutic agent for discogenic pain. JOR Spine 1: e1008-e1008.

O'Halloran DM, Pandit AS (2007) Tissueengineering approach to regenerating the intervertebral disc. Tissue Eng 13: 1927-1954.

Raj PP (2008) Intervertebral disc: anatomyphysiology-pathophysiology-treatment. Pain Pract 8: $18-44$.

Roberts AB, McCune BK, Sporn MB (1992) TGF- $\beta$ : regulation of extracellular matrix. Kidney Int 41: 557 559.

Shapiro IM, Risbud MV (2013) The intervertebral disc: molecular and structural studies of the disc in health and disease. Springer-Verlag Wien. DOI: 10.1007/978-3-7091-1535-0.

Smith LJ, Gorth DJ, Showalter BL, Chiaro JA, Beattie EE, Elliott DM, Mauck RL, Chen W, Malhotra NR (2014) In vitro characterization of a stem-cell- seeded triple-interpenetrating-network hydrogel for functional regeneration of the nucleus pulposus. Tissue Eng Part A 20: 1841-1849.

Thorpe AA, Boyes VL, Sammon C, Le Maitre CL (2016) Thermally triggered injectable hydrogel, which induces mesenchymal stem cell differentiation to nucleus pulposus cells: potential for regeneration of the intervertebral disc. Acta Biomater 36: 99-111.

Trout JJ, Buckwalter JA, Moore KC (1982) Ultrastructure of the human intervertebral disc: II. Cells of the nucleus pulposus. Anat Rec 204: 307-314.

van Dijk B, Potier E, Ito K (2011) Culturing bovine nucleus pulposus explants by balancing medium osmolarity. Tissue Eng Part C Methods 17: 1089-1096.

Van Vlierberghe S, Graulus GJ, Keshari Samal S, Van Nieuwenhove I, Dubruel P (2014) Porous hydrogel biomedical foam scaffolds for tissue repair. In: Biomedical foams for tissue engineering applications. Editor: Netti PA. Woodhead Publishing. pp: 335-390.

Wu PH, Kim HS, Jang I-T (2020) Intervertebral disc diseases part 2: a review of the current diagnostic and treatment strategies for intervertebral disc disease. Int J Mol Sci 21: 2135. DOI: 10.3390/ijms21062135.

Xia W, Liu W, Cui L, Liu Y, Zhong W, Liu D, Wu J, Chua K, Cao Y (2004) Tissue engineering of cartilage with the use of chitosan-gelatin complex scaffolds. J Biomed Mater Res B Appl Biomater 71: 373-380.

Yang W, Yu X-H, Wang C, He W-S, Zhang S-J, Yan Y-G, Zhang J, Xiang Y-X, Wang W-J (2015) Interleukin-1 $\beta$ in intervertebral disk degeneration. Clin Chim Acta 450: 262-272.

Zheng Y, Liang Y, Zhang D, Sun X, Liang L, Li J, Liu Y-N (2018) Gelatin-based hydrogels blended with gellan as an injectable wound dressing. ACS Omega 3: $4766-4775$.

\section{Web References}

1. Idataresearch.com [19-04-2021]

2. https://clinicaltrials.gov/ NCT01182337 [19-042021]

\section{Discussion with Reviewers}

Zhen Li: What are the main obstacles using the technique described in the present study for NP clinical regeneration?

Authors: The lack of therapeutic approaches in development for this under-served and growing market represents a significant opportunity for this technology. Furthermore, there are several distinct clinical indications within IVDD for the technology to be used either as a prophylactic/preventative stand-alone therapy or as an adjunctive therapy to surgical intervention. The main obstacles for NP clinical regeneration have been that we have mainly been reliant on academic research and that there has been a lack of pharmaceutical peptide development. 
Recently, we have started to industrialise the science and focus on drug development by availing ourselves of the adMare (adMare BioInnovations, Vancouver, Canada) capabilities and infrastructure. This will help achieving key preclinical development milestones to support investigational new drug (IND)-enabling studies, first-in-human $(\mathrm{FIH})$ clinical trials and financing.

Svenja Illien-Junger: You demonstrated that NPcells-seeded $\mathrm{CH}$-gelatine + LN hydrogels maintain cell viability and increase GAG production under degenerative conditions, which you suggested was due to the inhibitory role of LN on IL-1 $\beta$ pathways.
Would you expect a similar protective effect of LN on cell viability and GAG production by supplementing the degenerative medium with pro-inflammatory mediators such as lipopolysaccharide or TNF- $\alpha$ ?

Authors: Although LN can inhibit the signalling of IL-1, preliminary data suggested it had less effect on TNF- $\alpha$. Studies are underway to understand the protective effect of LN on cell viability and ECM production when degenerative medium is supplemented with lipopolysaccharide.

Editor's note: The Scientific Editor responsible for this paper was Mauro Alini. 